\title{
The Relationship between Self Regulated Learning Participants in Competency Test With Competency Test Results for Indonesian Midwives in South Sulawesi for the period July-September 2020
}

\author{
Zelna Yuni Andryani.A ${ }^{\mathbf{1}}$, Nurfaizah Alza ${ }^{2}$ \\ ${ }^{1}$ Fakultas Kedokteran dan Ilmu Kesehatan UIN Alauddin Makassar, zelna.yuni@uin-alauddin.ac.id \\ ${ }^{2}$ Fakultas Keperawatan dan Kebidanan Universitas Megarezky Makassar, nuricha303110@ gmail.com
}

\begin{abstract}
ABSTRAK
Latar Belakang : Pengaturan diri dalam belajar (Self-regulated learning) adalah sebuah konsep mengenai bagaimana seseorang peserta didik menjadi regulator atau pengatur bagi belajarnya sendiri . Self-regulation merupakan sebuah proses dimana seseorang peserta didik mengaktifkan dan menopang kognisi, perilaku, dan perasaannya yang secara sistematis berorientasi pada pencapaian suatu tujuan. Hasil belajar ditentukan oleh ikhtiar daripada tingkat kecerdasan. Ikhtiar yang dimaksud disini adalah mahasiswa mampu mengatur dirinya untuk belajar mandiri.

Tujuan : Penelitian ini bertujuan untuk mengetahui hubungan Self-regulated learning dengan Uji Kompetensi Bidan Indonesia.

Metode : Desain penelitian menggunakan survey analitik dengan pendekatan cross sectional study menggunakan teknik snow ball sampling dengan jumlah sampel 192 responden.

Hasil : penelitian menunjukkan tidak ada hubungan antara Self Regulated Learning dengan hasil Uji Kompetensi Bidan Indonesia dengan nilai $p=0,236$ ( $>$ nilai $\alpha$ ). Perlunya penelitian lanjut tentang faktor lain yang mempengaruhi hasil Uji Kompetensi Bidan Indonesia
\end{abstract}

\section{Kata Kunci : Self Regulated Learning, Uji Kompetensi Bidan}

\begin{abstract}
ABSTRAC
Background: Self-regulation in learning (Self-regulated learning) is a concept about how a student becomes a regulator for his own learning. Self-regulation is a process in which a student activates and supports cognition, behavior, and feelings which are systematically oriented towards achieving a goal. Learning outcomes are determined by effort rather than level of intelligence. The effort in question is that students are able to organize themselves to learn independently.

Purpose: : This study aims to determine the relationship between self-regulated learning and the Indonesian midwife competency test.

Methods: The research design used analytical survey with cross sectional study approach using snow ball sampling technique with a sample size of 192 respondents.

Results: The results showed that there was no relationship between Self Regulated Learning and the results of the Indonesian Midwives Competency Test with a value of $p=0.236$ ( $>\alpha$ value). The need for further research on other factors that affect the results of the Indonesian Midwives Competency Test.
\end{abstract}

Keywords: Self Regulated Learning, Midwives Competency Test

\section{PENDAHULUAN}

Tenaga kesehatan termasuk tenaga bidan merupakan garda terdepan dalam meningkatkan derajat kesehatan masyarakat. Fokus utama bidan adalah terkait dengan kesehatan ibu dan bayi, Angka Kematian Ibu (AKI) dan Angka Kematian Bayi (AKB) menjadi perhatian yang serius di Indonesia karena merupakan indikator keberhasilan pembangunan pada 
sektor kesehatan. Sehingga kompetensi tenaga bidan harus terstandar. Tenaga bidan yang tidak teruji kompetensinya dihawatirkan dapat menyumbang angka AKI dan AKB di Indonesia (1)

Bidan adalah salah satu sumber daya manusia yang memiliki peran dalam menurunkan AKI dan AKB. AKI dan AKB dapat diturunkan melalui program pelaksanaan Kesehatan Ibu dan anak (KIA). Salah satu prinisip pengolalaan KIA adalah meningkatkan deteksi dini faktor risiko dan komplikasi kebidanan. Pengolalaan KIA membutuhkan bidan yang kompeten yang dapat dicapai melalui Uji Komptensi Bidan Indonesia (UKBI). ${ }^{(2)}$

Pelaksanaan UKBI dilaksanakan dengan tujuan untuk menyamakan standar mutu lulusan pada setiap institusi pendidikan kebidanan. Harapan setiap institusi pendidikan kebidanan adalah seluruh Lulusan lulus dalam menghadapi ujian kompetensi, namum dibeberapa institusi pendidikan pada kenyataannya tidak seperti apa yang diharapkan. Jumlah kelulusan ujian kompetensi tidak merata di seluruh Indonesia, ada yang jumlah kelulusannya 90-100\% dan ada yang jumlah kelulusannya hanya mencapai 10$30 \%$ pada setiap periode ujian kompetensi. Bagi Lulusan ujian kompetensi merupakan suatu tantangan yang harus dihadapi karena pada saat ini syarat untuk melamar pekerjaan bagi tenaga kesehatan adalah harus memiliki STR (Surat Tanda Registrasi). STR diperoleh apabila seorang mahasiswa dinyatakan lulusan (kompeten) pada pelaksanaan Uji Kompetensi. (3)

Uji kompetensi tenaga kesehatan adalah proses untuk mengukur pengetahuan, keterampilan, dan sikap tenaga kesehatan sesuai dengan standar profesi. Bidan merupakan tenaga kesehatan yang juga dituntut untuk lulus uji kompetensi sebagai prasyarat mendapatkan Surat Tanda Registrasi (STR) sebagai salah satu bukti legalitas praktik profesi di lahan kerja. (4)

Uji kompetensi adalah metode untuk mengevaluasi kemampuan kognitif, afektif dan psikomotor tenaga profesi kesehatan. Uji kompetensi merupakan salah satu instrumen manajemen mutu, yakni menerapkan standar yang berlaku secara nasional untuk menghasilkan informasi untuk membuat keputusan mengenai seberapa pendidikan sudah memenuhi standar, termasuk para peserta didik apakah mereka memenuhi standar mutu yang berlaku pada jenjang/jenis pendidikan yang ditempuh. Tenaga kesehatan yang lulus uji kompetensi akan diberikan sertifikat kompetensi sebagai bukti pengakuan terhadap kompetensi yang dimiliki, menjadi landasan registrasi dan lisensi/perizinan untuk melakukan pekerjaan profesi. Hal ini dimaksudkan agar pelayanan kepada masyarakat di seluruh wilayah Indonesia memiliki standar mutu yang sama. Hasil uji kompetensi mahasiswa dipengaruhi oleh faktor eksternal, meliputi: Try Out, kurikulum/metode pembelajaran, faktor dosen, faktor lain yang berpengaruh, sedangkan faktor internal meliputi: kecerdasan, minat dan bakat, motivasi dan belajar mandiri. Beberapa faktor tersebutlah yang dapat mempengaruhi hasil uji kompetensi mahasiswa. ${ }^{(5,14)}$

Pengaturan diri dalam belajar (Selfregulated learning) adalah sebuah konsep mengenai bagaimana seseorang peserta 
didik menjadi regulator atau pengatur bagi belajarnya sendiri mengatakan bahwa selfregulation merupakan sebuah proses dimana seseorang peserta didik mengaktifkan dan menopang kognisi, perilaku, dan perasaannya yang secara sistematis berorientasi pada pencapaian suatu tujuan. Hasil belajar ditentukan oleh ikhtiar daripada tingkat kecerdasan. Ikhtiar yang dimaksud disini adalah mahasiswa mampu mengatur dirinya untuk belajar mandiri. ${ }^{(6)}$ Pada proses pembelajaran, mahasiswa melakukan suatu kegiatan untuk dirinya sendiri sehingga mereka bisa memahami bagaimana belajar dan bekerja untuk dirinya sendiri. Hal ini diperlukan model pembelajaran yang memberikan kesempatan (autonomi) kepada siswa untuk melakukan dan mengelola sendiri pembelajarannya yaitu model regulasi diri dalam belajar (Self Regulated Learning). ${ }^{(9)}$

Wine (dalam Santrock, 2009) meyatakan karakteristik dari pelajar yang mempunyai regulasi diri dalam pembelajaran diantaranya bertujuan memperluas penetahuan dan menjaga motivasi, menyadari keadaan emosi mereka dan punya strategi untuk mengelola emosinya, secara periodik memonitor kemajuan ke arah tujuannya, menyesuaikan atau memperbaiki strategi berdasarkan kemajuan yang mereka buat, mengevaluasi halangan yang mungkin muncul dan melakukan adaptasi yang diperlukan. ${ }^{(7)}$

Maka dari itu, peneliti bermaksud menganalisis hubungan Self Regulated Learning (SRL) peserta uji kompetesi dengan hasil Uji Kompetensi Bidan Indonesia Di Sulawesi Selatan Periode JuliSeptember Tahun 2020.

METODE

Jenis penelitian ini adalah penelitian kuantitatif dengan pendekatan analitik observasional menggunakan studi cross sectional. Data dikumpulkan melalui kuesioner online yang didistribusikan pada peserta ukom alumni kebidanan di Sulawesi-selatan. Teknik pengambilan sampel menggunakan snowball sampling yaitu suatu teknik yang multitahapan, didasarkan pada analogi bola salju, yang dimulai dengan bola salju yang kecil kemudian membesar secara bertahap karena ada penambahan salju ketika digulingkan dalam hamparan salju. ${ }^{(8)}$

Data di analisis secara univariat untuk melihat distribusi frekuensi karakteristik responden. Selain itu, juga dilakukan analisis bivariat menggunakan uji fisher untuk membandingkan antara hasil ujian kompetensi peserta dengan, tingkat SRL, dan status ujian kompetensi.

\section{HASIL}

\section{Analisis Univariat}

Tabel 1. Distribusi Frekuensi Usia Alumni Kebidanan Saat Mengikuti Ujian Kompetensi di Sulawesi Selatan Tahun 2020

\begin{tabular}{ccc}
\hline Usia & Frekuensi & $(\%)$ \\
\hline$\geq 25$ Tahun & 69 & 35,9 \\
$<25$ Tahun & 123 & 64,1 \\
\hline
\end{tabular}


Berdasarkan tabel 1. Dapat diketahui Kebidanan di Sulawesi-selatan pada tahun bahwa mayoritas peserta Ukom Alumni 2020 berusia $<25$ tahun $(64,1 \%)$

Tabel 2. Distribusi Frekuensi Keikutsertaan Ujian Kompetensi Pada Lulusan Kebidanan di Sulawesi Selatan Periode Juli-September Tahun 2020

\begin{tabular}{ccc}
\hline Status UKOM & Frekuensi & $\mathbf{( \% )}$ \\
\hline First Taker & 66 & 34,4 \\
Re Taker & 126 & 65,6
\end{tabular}

Berdasarkan tabel 2. Dapat diketahui bahwa mayoritas peserta Ukom Alumni Kebidanan di Sulawesi-selatan pada tahun
2020 merupakan re taker yaitu sebanyak 126 responden atau sebesar $65,6 \%$ dari total responden yang diteliti

Tabel 3. Distribusi Frekuensi Tingkat Self Regulated Learning Sebelum Mengikuti Ujian Kompetensi Pada Alumni Kebidanan di Sulawesi Selatan Tahun 2020

\begin{tabular}{ccc}
\hline Tingkat SRL & Frekuensi & $\mathbf{( \% )}$ \\
\hline Tinggi & 100 & 52,1 \\
Rendah & 92 & 47,9 \\
\hline
\end{tabular}

Berdasarkan tabel 3. Dapat diketahui bahwa mayoritas peserta Ukom Alumni Kebidanan diSulawesi-selatan pada tahun
2020 memiliki tingkat SLR yang tinggi yaitu sebanyak 100 responden atau sebesar $52,1 \%$ dari total responden yang diteliti

Tabel 4. Distribusi Frekuensi Hasil Ujian Kompetensi Alumni Kebidanan di Sulawesi Selatan Tahun 2020

\begin{tabular}{ccc}
\hline Hasil UKOM & Frekuensi & $(\boldsymbol{\%})$ \\
\hline Kompeten & 58 & 30,2 \\
Tidak Kompeten & 134 & 69,8
\end{tabular}

Berdasarkan tabel 4. Dapat diketahui bahwa mayoritas peserta Ukom Alumni Kebidanan di Sulawesi-selatan pada tahun 2020 memiliki hasil yang tidak kompeten yaitu sebanyak 134 responden atau sebesar $69,8 \%$ dari total responden yang diteliti.responden atau sebesar $64,1 \%$ dari total responden yang diteliti.

Analisis Bivariat

Tabel 5. Hubungan Tingkat SRL dengan Hasil Ujian Kompetensi Pada Alumni

\begin{tabular}{cccc}
\multicolumn{4}{c}{ Kebidanan di Sulawesi Selatan Tahun 2020} \\
\hline $\begin{array}{c}\text { Tingkat } \\
\text { SRL }\end{array}$ & Kompeten & $\begin{array}{c}\text { Tidak } \\
\text { Kompeten }\end{array}$ & p \\
\hline Tinggi & 33 & 67 & 0,236 \\
Rendah & 25 & 67 &
\end{tabular}


Berdasarkan tabel 5. Dapat diketahui bahwa secara statistik tidak terdapat hubungan antara tingkat SRL dengan hasil

\section{PEMBAHASAN}

\section{Hubungan tingkat SRL dengan hasil ukom}

Hasil penelitian menunjukkan bahwa tidak terdapat hubungan antara hasil ukom dan tingkat SRL (Self Regulated Learning) alumni kebidanan di Sulawesi-Selatan. Hal ini sejalan dengan Penelitian yang dilakukan oleh Supriyanto tahun 2015 juga menunjukkan bahwa SRL tidak berhubungan dengan prestasi akademik mahasiswa tahun pertama Prodi Psikologi Universitas Pembangunan Jaya ( $\mathrm{p}$-value 0,29). Menurut penelitian tersebut hal ini dapat disebabkan oleh perbedaan individual yang menentukan perbedaan kapasitas SRL. Individu yang berbeda dapat menggunakan strategi belajar yang berbeda ketika menghadapi situasi yang sama. Namun individu yang sama juga dapat menggunakan strategi belajar yang berbeda untuk menghadapi situasi yang berbeda. Kemampuan seseorang untuk belajar, berpikir dan menyelesaikan masalah belajar juga dipengaruhi oleh adaptasi terhadap nilai-nilai, kepercayaan, kebiasaan yang berkembang dalam lingkungan sosial dan budaya mereka. Demikian juga dengan cara orangtua dalam mengarahkan anaknya memecahkan masalah akan mempengaruhi anak tersebut dalam belajar mandiri.

Menurut Suryabrata ada faktor lain yang mempengaruhi hasil belajar/hasil uji kompetensi yaitu lingkungan yang menjadi faktor eksternal, kondisi fisik dan psikologis yang merupakan faktor internal. ${ }^{(\mathbf{1 2}, 13)}$ Hal ini sejalan dengan penelitian Ferawati tahun 2020 bahwa ada ujian kompetensi alumni kebidanan di Sulawesi-selatan pada tahun 2020

hubungan kecemasan/kondisi psikologis dengan hasil uji kompetensi Bidan. Jadi dapat disimpulkan bahwa walaupun pengaturan diri mahasiswa dalam belajar cukup baik tetapi dengan kondisi cemas dalam menghadapi uji kompetensi dapat mempengaruhi tingkat kegagalan uji kompetensi Bidan Indonesia (UKBI). ${ }^{(15)}$

Self regulated learning dipengaruhi oleh banyak faktor, diantaranya modelling dan self-efficacy. Modelling merupakan sumber penting untuk menyampaikan keterampilan-keterampilan pengaturan diri. Di antara keterampilan pengaturan diri di mana model dapat terlibat adalah perencanaan dan pengelolaan waktu secara efektif, perhatian dan konsentrasi, pengorganisasian dan pengodean informasi secara strategis, pembentukan lingkungan kerja yang produktif dan penggunaan sumber-sumber sosial. Keberadaan self regulated learning di tentukan oleh tiga wilayah yakni wilayah person, wilayah perilaku dan wilayah lingkungan. (10)

\section{KESIMPULAN}

Dari hasi penelitian dapat disimpulkan bahwa self regulated learning tidak memiliki hubungan dengan hasil uji kompetensi bidan Indonesia. Hal ini dikarenakan ada faktor lain yang paling menonjol yaitu kondisi psikologis/kecemasan dari peserta uji kompetensi di Sulwesi Selatan periode JuliSepetember tahun 2020.

\section{SARAN}

Peserta ukom menyiapkan diri bukan hanya secara keilmuan tetapi juga 
secara mental sebagai kesiapan menghadapi UKBI, Perlunya dukungan secara psikososial dan spiritual terhadap lulusan yang akan mengikuti uji kompetensi dan untuk penelitian lanjut tentang faktor lain yang mempengaruhi self Regulated Learning

\section{DAFTAR PUSTAKA}

1. Dirjen Dikti Kemedikbud. Standar Kompetensi Bidan ; 2011 https:// fdokumen.com/ document/184-draft-standar-kompetensi-bidan-2011pdf.html, diakses tanggal 08 Desember 2020

2. Kemenkes. Survey Demografi dan Kesehatan Indonesia (SDKI).http:// kesga. kemkes. go.id/images/pedoman/SDKI\%202012-Indonesia.pdf;2012

3. Hayati, Rahmah Nur. Pengaruh Pengetahuan, Sikap Dan Motivasi Terhadap Minat Bidan Mengikuti Uji Kompetensi Di Kota Semarang Tahun 2007: http:// eprints. undip.ac.id/ 18812/1/RAHMAH_NUR_HAYATI.pdf, diakses tanggal 08 Desember 2020

4. Benny Andreson Situmorang, Kristina L Silalahi. Pengaruh Focus Group Discussion Tentang Pelaksanaan Uji Kompetensi Terhadap Tingkatkecemasan Mahasiswa. Universitas Prima Indonesia; 2019

5. Ayu Hartina, Takdir Tahir, Nurhaya Nurdin, Midawati Djafar. Faktor Yang Berhubungan Dengan Kelulusan Uji Kompetensi Ners Indonesia (Ukni) Di Regional Sulawesi: http:// jurnalppni.org/ojs/index.php/jppni/article/view/84/37, diakses tanggal 08 Desember 2020

6. Alkautzar, Anieq Mumthi'ah. Hubungan Kecerdasan Emosional, Kecerdasan Spiritual Dan Regulasi Diri Dalam Belajar (Self-Regulated Learning) Terhadap Hasil Ujian Osca Mahasiswa Kebidanan Stikes Mega Rezky Makassar. Makassar:Journal Of Islamic Nursing;2018

7. Ishtifa Hanny. Pengaruh Self-Efficacy dan Kecemasan Akademis Terhadap Self-Regulated Learning Mahasiswa Fakultas Psikologis Universitas Islam Negeri Jakarta;2011

8. Dahlan M. Sopiyuddin. Statisitik. Jakarta: Epidemiologi Indonesia; 2017

9. Mukhid. (2008).Strategi Self-Regulated Learning (Perspektif Teoritik).(Online).Tadris.Volume 3.Nomor 2. (http://download.portalgaruda.org/article.php) diakses tanggal 8 Desember 2020

10. Zimmerman,B.J, Martinez-Pons.Student Differences In Self-Regulated Learning:Relating Grade,Sex, and Giftedness to Self-Efficacy and Strategi Use.Journal of Educational Psychology, Vol.82,No.1,51-59;1990

11. Supriyanto. Hubungan Antara Self-Regulated Learning dan Prestasi Akademik pada Mahasiswa Semester Pertama Prodi Psikologi Universitas Pembangunan Jaya;2015

12. Firdaus Safira,Rachman Lutfi, Firmansyah Marindra. Analisa Faktor Pengaruh Self-Regulated Learning Terkait Performance Goals Terhadap Prestasi Akademik;2015

13. Sitepu B.P. Pengembangan Sumber Belajar. Jakarta : Rajawali Press;2014

14. Kementerian Riset Teknologi dan Pendidikan Tinggi (Kemenristedikti). Data Statistis Tingkat Kelulusan Uji Kompetensi Bidan. 2018. Tersedia dari: http://ukbidan.ristekdikti.go.id/pages/statist ik_lulus ,diakses 11 Desember 2020

15. Taherong Ferawati. Hubungan Tingkat Kecemasan dan Frekuensi Keikutsertaan Uji Kompetensi Dengan Hasil Uji Kompetensi Bidan Nasional (UKBI) di Sulawesi Selatan Periode JuliSepetember;2020 